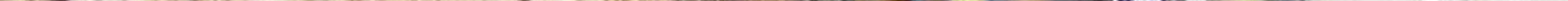




\title{
Older Adults' Contributions to the Tsimane Forager-Farmer Economy
}

\author{
Eric Schniter \\ Economic Science Institute, Chapman University
}

An older woman tends a fire, roasting plantains while a pet monkey climbs nearby. At a village gathering, an older man beats a bombo, providing a steady bass drum beat for a flute player. The flute sketches the melody of a well-known song that begs the mythical animal guardians to keep delivering game to the local hunting grounds. Her white hair alit by a ray of morning sunshine, a woman grasps for her granddaughter's head, hoping to groom her a bit. As her daughter and grandson look on, another grandmother prepares yuca porridge that she will later masticate and let ferment into shocdye', a home-brewed manioc beer that is not only an important dietary staple, but also an important component of social life (Hooper et al., 2013).

These snapshots of Tsimane older adults' skills and services provide us a fleeting glimpse of their complimentary contributions in a quickly changing forager-farmer economy. Older Tsimane are generally supported by kin and non-kin alike, receiving honorary titles like jayej (grandmother) or via' (grandfather). Older Tsimane are respected because they are said to chij dyiji'jiyequi, or "know how to think (about work and what needs to be done)". In other words, older Tsimane excel in their ability to efficiently plan and execute tasks as well as to maintain the harmony among family and community relations. Based on this wisdom and experience as well as their regular contributions to kin and non-kin alike, older adults have carved themselves an important niche in this forager-farmer society.

The Tsimane are an indigenous group living in the Bolivian Amazon. Despite contact with Jesuit missionaries in the late 17th century, Tsimane have remained relatively unacculturated to the larger Bolivian society. To make a living, Tsimane have traditionally practiced gardening, hunting, fishing and collecting. More recently their involvement in the cash economy has increased with those who have access to the local market selling agricultural produce and with younger adults laboring for wages on ranches and in logging camps. Tsimane currently number approximately 11,000 people and live in three or four generational extended family clusters, scattered throughout approximately 90 villages.

Research on Tsimane skill development has shown that most of their basic skills (e.g., food production, childcare, craft production) are acquired by early adulthood and gradually developed to meet children's growing demands (Schniter et al., 2014). As adults age into their grandparental years, they continue to make important

Anthropology \& Aging, Vol 35, No 1 (2014), pp. 56-58

ISSN 2374-2267 (online) DOI 10.5195/aa.2014.62

\section{(c)) EY-NC-ND}

This work is licensed under a Creative Commons Attribution-Noncommercial-No Derivative Works 3.0 United States License.

This journal is published by the University Library System of the University of Pittsburgh as part of its D-Scribe Digital Publishing Program, and is cosponsored by the University of Pittsburgh Press. 
contributions to kin, but increasingly do so via complimentary services such as caretaking, teaching, and chores. When parents leave or die and children need surrogate caretakers, grandparents are often the first line of defense (Gurven \& Schniter, 2010). Grandparents are identified among primary sources of skill transmission (whether as active teachers or passive exemplars), and are twice as likely to be identified as sources from which rare but important skills were learned, such as making pottery, punishing bad behavior, singing traditional songs, and telling old stories and myths (Schniter, 2009). Despite greater physical frailty than younger adults who may outperform their seniors on strength-intensive tasks, older adults are often regarded by others as experts. For example, they are regarded as the best musicians and storytellers, consistent with their roles as teachers.

Among forager-farmer groups like the Tsimane, skills in the oral tradition have been crucial to the process of enculturation, socialization, and education (Coe, 2006). Prior to the introduction of modern scholastic education and popular media from non-Tsimane sources, the role of educator and entertainer fell on local experts, especially older adults who are well positioned to broadcast their cumulative knowledge to attentive ears (Scalise Sugiyama, 2011). Still today, when vats of home-brewed beer are made available and family and neighbors gather to drink them, older adults take advantage of the social opportunities, broadcasting their culture and knowledge through musical performance and storytelling (Iamele, 2001). These domestic and social activities, connected in operational chains with gardeners, food processors, brewers, and consumers, form the social fabric of cooperation and intergenerational pedagogy that has been a hallmark of forager and horticultural societies (Jennings et al, 2005; Schniter, 2009).

Whether future generations of Tsimane will continue to respect and support older adults, and whether older adults will continue to have opportunities to make intergenerational contributions such as the ones highlighted in this portfolio is uncertain. As modern schooling and novel forms of information broadcast and entertainment (television and movies, the radio, news media, the Internet) increasingly bombard forager-farmer societies like the Tsimane - the perceived value of traditional musical and oral tradition diminishes. Likewise, as home-brewed beer production is crowded out by the sugar cane liquor that exploitative merchants increasingly trade for Tsimane products (Añez, 1992), community gatherings become less inclusive and alcoholism more common. As a consequence, the age-old systems that have been maintained over generations, where people gather socially and culture is transmitted from old to young, break down (Zent, 2001). In the absence of these meaningful transfers across generations, functional disability and social conflict contribute to depression among older Tsimane (Stieglitz et al., 2014).

While centuries of cultural isolation may have helped the Tsimane conserve their system of intergenerational cooperation and older adult contributions, the future will present them new challenges. Older adults' contributions to their forager-farmer economy have been possible because of their comparative advantages and accumulated knowledge that comes with age. Successful aging among adults of future generations will hinge on younger generations maintaining an appreciation for older adults' roles as trusty helpers, educators, and cultural experts. 


\section{References}

Añez, Jorge

1992 The Chimane experience selling jatata. In Sustainable Harvest and Marketing of Rainforest Products. Mark J. Plotkin, Lisa Famolare eds. New York: Island Press.

Coe, Kathryn

2003 The Ancestress Hypothesis: Visual Art as Adaptation. New Jersey: Rutgers University Press.

Gurven, M., and Schniter, E.

2010 An Evolutionary Perspective Can Help Unify Disparate Accounts of Grandparental Investment. Behavioral and Brain Sciences. 33: 25-26.

Hooper, P. L., DeDeo, S., Caldwell Hooper, A. E., Gurven, M., \& Kaplan, H. S.

2013 Dynamical Structure of a Traditional Amazonian Social Network. Entropy, 15(11), 4932-4955.

Iamele, Giuseppe

2001 Palabras Antiguas y Nuevas del Rio Quiquibey, en la Amazonia Boliviana. Programa Regional de Apoyo a los Pueblos Indígenas de la Cuenca de Amazonas (PRAIA): Bolivia.

Jennings, J, Antrobus, K.L., Atencio, S.J., Glavich, E., Johnson, R., Loffler, G., and Luu, C.

2007 Drinking Beer in a Blissful Mood: Alcohol Production, Operational Chains, and Feasting in the Ancient World. Current Anthropology, 46(2): $275-303$.

Scalise Sugiyama, Michelle

2011 The Forager Oral Tradition and the Evolution of Prolonged Juvenility. Frontiers in Psychology, 2:133.

Schniter, Eric

2009 Why Old Age: Non-material contributions and patterns of aging among older adult Tsimane'. Dissertation: University of California, Santa Barbara

Schniter, E., Gurven, M., Kaplan, H., Wilcox, N., and Hooper, P.

2014 Skill Ontogeny among Tsimane Forager-Horticulturalists. Working Paper; Economic Science Institute, Chapman University. http://www.chapman.edu/research-and-institutions/economic-science-institute/ files/WorkingPapers/ Schniteretal2014SkillOntogenyTsimane.pdf accessed 27 November, 2014

Stieglitz, J., Schniter, E., von Rueden, C., Kaplan, H., \& Gurven, M.

2014 Functional Disability and Social Conflict Increase Risk of Depression in Older Adulthood Among Bolivian ForagerFarmers. Journals of Gerontology, Series B: Psychological and Social Sciences, doi:10.1093/geronb/gbu080

Zent, Stanford

2001 Acculturation and Ethnobotanical Knowledge Loss among the Piaroa of Venezuela. In On Biocultural Diversity: Linking Language, Knowledge, and the Environment, L. Maffi ed. Pp. 190-211. Harper Collins. 